\title{
Takotsubo cardiomyopathy resulting from exacerbation of chronic pancreatitis
}

\author{
Kardiomiopatia takotsubo wynikająca \\ z zaostrzenia przewlekłego zapalenia trzustki
}

\author{
Marta Garbowska ${ }^{1}$, Krzysztof Kurek $^{2}$, Bożena Sobkowicz ${ }^{1}$ \\ ${ }^{1}$ Medical University of Bialystok, Department of Cardiology \\ ${ }^{2}$ Medical University of Bialystok, Department of Gastroenterology and Internal Medicine
}

\begin{abstract}
Takotsubo cardiomyopathy (TCM) is a medical condition characterized by a transient left ventricular apical dysfunction with unknown etiology. The clinical presentation mimics acute myocardial syndrome in the absence of obstructive coronary artery disease. The association between acute pancreatitis and TCM, however, is rarely reported in the literature. To date, no cases of TCM resulting from the exacerbation of chronic pancreatitis have been described.
\end{abstract}

Key words: takotsubo cardiomyopathy, chronic pancreatitis, echocardiography

Folia Cardiologica 2016; 11, 5: 473-476

\section{Introduction}

Originally described in 1990 by Japanese scientists takotsubo cardiomyopathy (TCM), also known as broken heart syndrome, stress cardiomyopathy or left ventricular apical ballooning, constitutes about $2 \%$ of all acute coronary syndrome cases [1,2]. Classically in TCM, the appearance of the left ventricle during the coronarography procedure mimics the shape of an octopus trap named "tako tsubo". Multiple psychological (e.g. emotional stress) and physical (e.g. pheochromocytoma, sub-arachnoid hemorrhage, reperfusion injury) triggers have been reported previously $[3,4]$. Besides the causes of TCM presented above, also acute pancreatitis (via exaggeration of sympathetic stimulation that leads to transient myocardial dysfunction and microvascular hypoperfusion distributive shock) could act as a trigger for TCM. To date, only a few cases of acute pancreatitis induced TCM have been described [5-7]. We present, to the best of our knowledge, first case report of TCM resulting from the exacerbation of chronic pancreatitis.

\section{Case report}

A 47-year-old female, with four-year history of alcohol-related chronic pancreatitis, was admitted to an emergency department with acute epigastric pain, concomitant nausea, previous vomiting lasting 7 days followed by chest pain and dyspnea lasting 2 days. Physical examination of the patient revealed clinical signs of circulatory shock, including $R R$ 80/50 mm Hg, HR 110 bpm and diffuse abdominal pain with palpable mass in the left epigastrium. Performed during the admission 12-lead ECG demonstrated ST-T elevation in V2 lead (max. $2 \mathrm{~mm}$ ) (Fig. 1). Moreover, blood parameters at admission demonstrated increased white blood cells (WCB $\left.19.52 \times 10^{3}\right)$, procalcitonin $(146.43 \mathrm{ng} / \mathrm{mL}$; N: $<0.5$ ), C-reactive protein (CRP $293.8 \mathrm{mg} / \mathrm{L} ; \mathrm{N}: 0-10$ ), serum

Address for correspondence: dr n. med. Krzysztof Kurek, Klinika Gastroenterologii i Chorób Wewnętrznych, Uniwersytet Medyczny w Białymstoku, ul. Marii Skłodowskiej-Curie 24a, 15-275 Białystok, Poland, e-mail: krzysztof.kurek@umb.edu.pl 


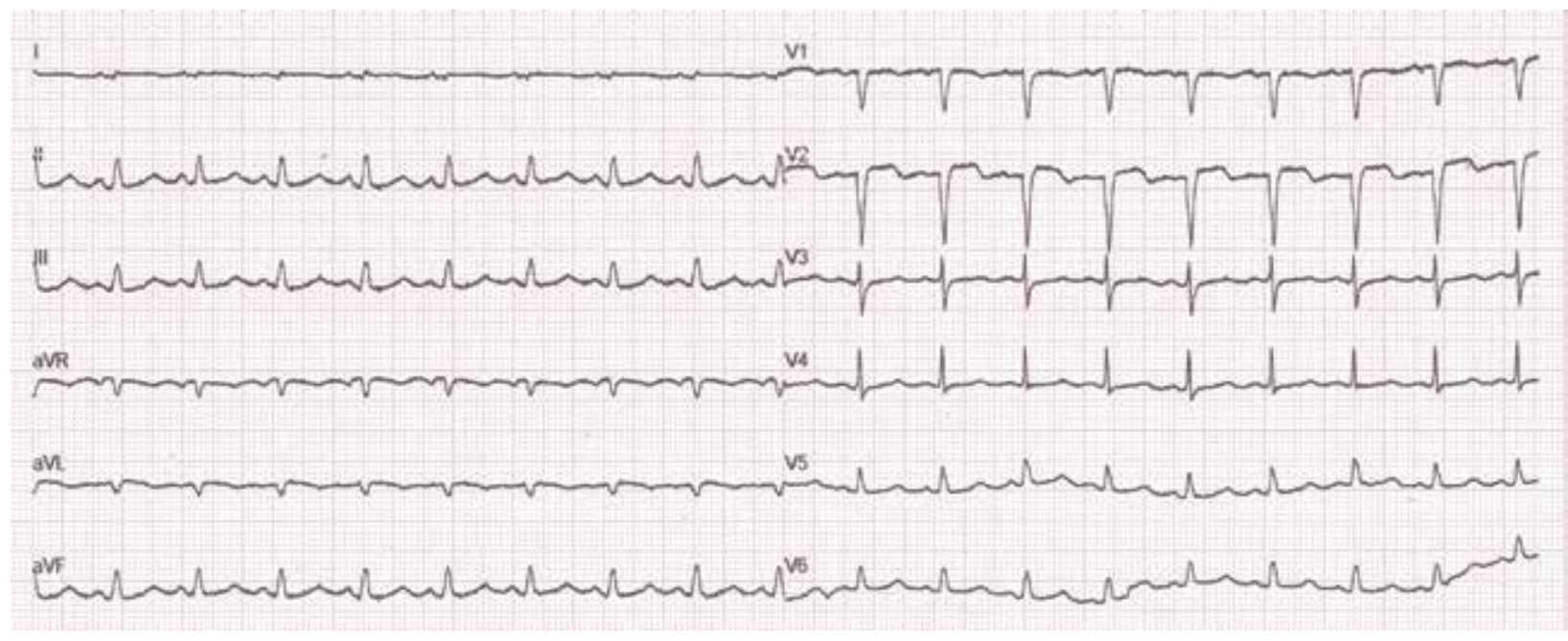

Figure 1. Initial 12-lead electrocardiogram with ST-T elevation in V2 lead

amylase (455.0 IU/L; N: < 90) and lipase (> $1200 \mathrm{IU} / \mathrm{L}$; $\mathrm{N}: 7-60)$, urine amylase (1703 IU/L; N: 0-480), aspartate transaminase (188 IU/L; N: 5-50), alanine transaminase (109 IU/L; N: 5-50), high-sensitivity troponin I (9649.8 ng/L; N: 0-15.6) and N-terminal pro-beta natriuretic polypeptide (2503.7 pg/mL; N: 0-100) levels. Abdominopelvic computed tomography showed features of exacerbated chronic pancreatitis (dilation of the main pancreatic duct, pancreatic calcification, stranding of the peripancreatic fat tissue and large walled-off fluid collection in the tail of pancreas) (Fig. 2). Initial transthoracic echocardiography (TTE) revealed apical ballooning and hyper-contractile basal segments of the left ventricle (LV). Medical management of acute coronary syndrome included aspirin, clopidogrel and atorvastatin administration. Urgent coronary angiography demonstrated normal coronary arteries. Left ventriculography showed apical hypokinesis

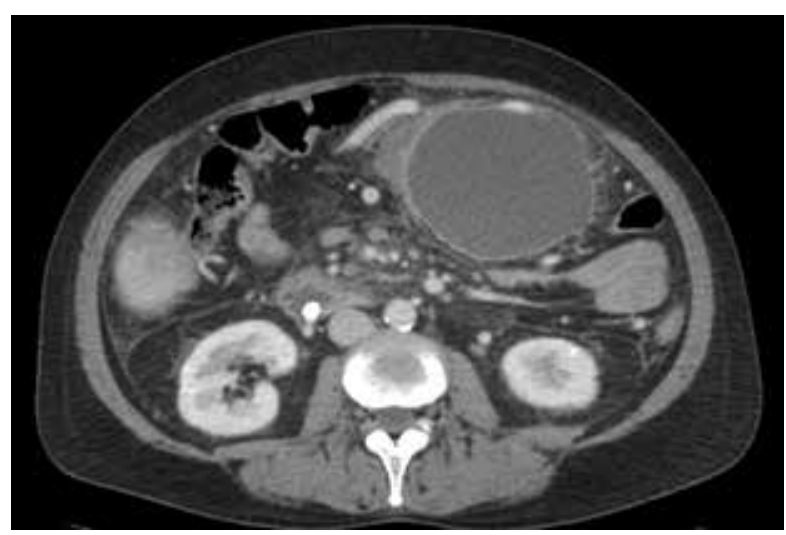

Figure 2. Computed tomography examination showing features of chronic pancreatitis (dilation of the main pancreatic duct, pancreatic calcification and large walled-off fluid collection in pancreatic tail)

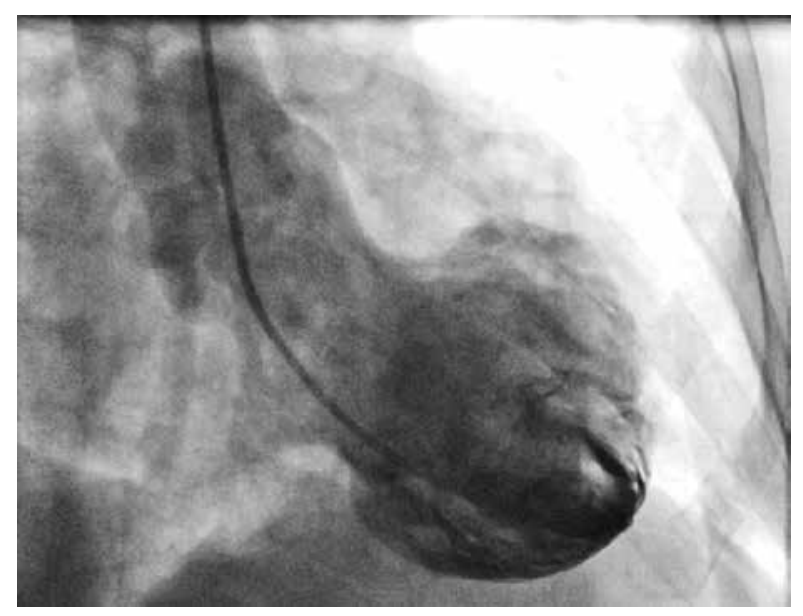

Figure 3. Left ventriculography demonstrating reduced ejection fraction and apical hypokinesis

with reduced ejection fraction (25\%) (Fig. 3). In the light of the above symptoms and normal coronary arteries, a diagnosis of takotsubo cardiomyophaty was established. The examination of the patient's chest X-ray excluded pulmonary congestion (Fig. 4). Ultrasound examination revealed the collapsed inferior vena cava and the jugular veins. Therefore, distributive shock due to pancreatitis was diagnosed. Clinical improvement was obtained after intensive intravenous hydration (up to 4 liters of crystalloids per day). Moreover, antibiotics and analgesics were administered in line with the typical conservative treatment of exacerbated chronic pancreatitis. Over the next 3 days symptoms of pancreatitis were alleviated, the laboratory tests results significantly improved, and, as a result, the patient was able to tolerate oral food intake. After a 10-day follow-up, the left ventricle function (as measured by TTE) recovered with an estimated ejection fraction at the level of 


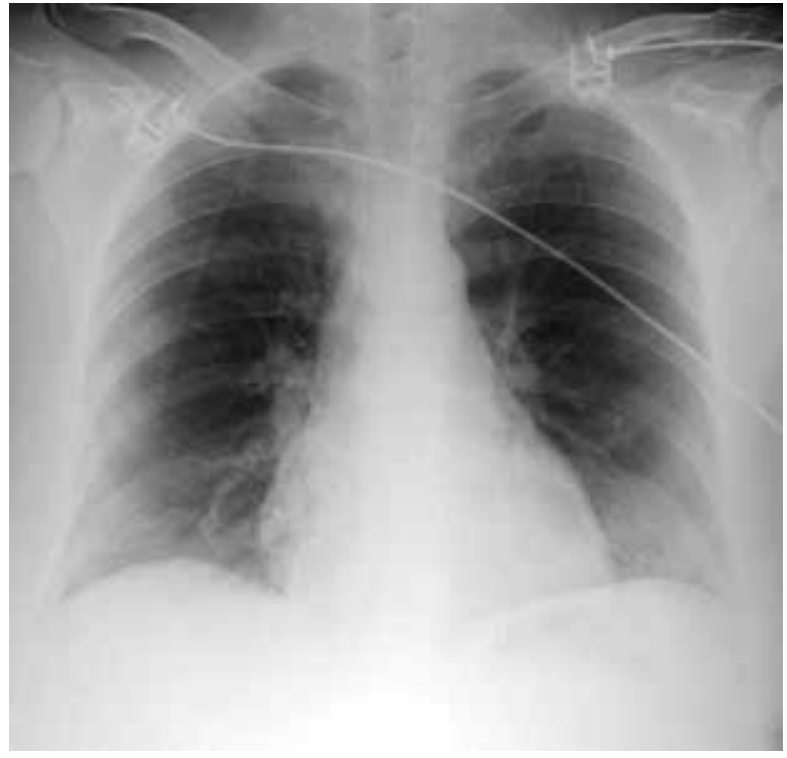

Figure 4. Initial chest X-ray showing no signs of pulmonary congestion

$48 \%$. The patient was counselled about alcohol cessation. Further surgical and/or endoscopic treatment of the above-mentioned pancreatic fluid collection was also planned.

\section{Discussion}

Takotsubo cardiomyopathy is a reversible cardiomyopathy with a clinical presentation indistinguishable from myocardial infarction. TCM occurs commonly amongst postmenopausal women and is frequently preceded by physiological or emotional stress. Although the exact cause of TCM is currently unknown coronary microvascular dysfunction and catecholamine toxicity are nowadays widely accepted as its underlying pathological mechanism. Nevertheless, there are also other factors possibly involved in TCM pathogenesis, i.e. coronary spasm, ischemic-reperfusion injury and microinfarction [5, 8]. The Mayo Clinic diagnostic criteria defined TCM as: 1) transient hypokinesis, akinesis, or dy- skinesis of the left ventricular mid-segments with or without apical involvement; 2) absence of obstructive coronary disease or angiographic evidence of acute plaque rupture; 3) new electrocardiographic abnormalities (ST-segment elevation and/or T-wave inversion) or modest elevation in cardiac troponin; and 4) absence of pheochromocytoma or myocarditis [9]. In the light of these considerations, the diagnosis of TCM in the case of our patient was established correctly.

The possibility of a correlation between alcoholic pancreatitis and TCM was first established in 2006 [10]. Acute pancreatitis as well as the exacerbation of chronic pancreatitis are substantial stressors that precede and possibly cause TCM. There are a few potential mechanisms for these stressors actions. First of all, pancreatitis increases, associated with the occurrence of TCM, sympathetic stimulation of the heart [11]. Moreover, pancreatitis is often associated with distributive shock that in turn leads to transient myocardial ischemia and microvascular hypoperfusion [5]. Both of these mechanisms are postulated pathophysiological backdrop to TCM. In the case of our patient distributive shock was diagnosed based on the initial clinical symptoms (hypotension, tachycardia), as confirmed by ultrasound examination that revealed the collapsed inferior vena cava and the jugular veins. Moreover, also clinical improvement of the patient (obtained after intensive intravenous hydration) confirms the role of distributive shock in TCM pathogenesis.

In conclusions, in the present paper we have reported, presumably for the first time, the case of TCM resulting from the exacerbation of chronic pancreatitis. Moreover, also previously published case reports highlighted the association of acute pancreatitis with $\operatorname{TCM}[5,12]$. Further clinical studies are needed to clarify the pathophysiology of TCM and to standardize the care of these patients.

\section{Conflict of interest(s)}

The authors declare no conflict of interests regarding the publication of this article.

\section{Streszczenie}

Kardiomiopatia takotsubo charakteryzuje się przejściową dysfunkcją koniuszka lewej komory o nieznanej etiologii. Obraz kliniczny przypomina ostry zespół wieńcowy przy braku nieprawidłowości w naczyniach wieńcowych. Dotychczas opublikowano nieliczne przypadki zależności między kardiomiopatią takotsubo a ostrym zapaleniem trzustki. Jak dotąd nie opisano jednak przypadku kardiomiopatii takotsubo wynikającej z zaostrzenia przewlekłego zapalenia trzustki.

Słowa kluczowe: kardiomiopatia takotsubo, przewlekłe zapalenie trzustki

Folia Cardiologica 2016; 11, 5: 473-476 


\section{References}

1. Sato H., Tateishi H., Uchida T. Takotsubo-type cardiomyopathy due to multivessel spasm. In: Kodama K, Haze K, Hon M eds. Clinical aspect of myocardial injury: from ischemia to heart failure. Kagakuhyouronsha, Tokyo 1990: 56-64.

2. Eshtehardi P., Koestner S.C., Adorjan P. et al. Transient apical ballooning syndrome - clinical characteristics, ballooning pattern, and long-term follow-up in a Swiss population. Int. J. Cardiol. 2009; 135: 370-375.

3. Roshanzamir S., Showkathali R. Takotsubo cardiomyopathy a short review. Curr. Cardiol. Rev. 2013; 9: 191-196.

4. Rajani R., Przedlacka A., Saha M., de Belder A. Pancreatitis and the broken heart. Eur. J. Emerg. Med. 2010; 17: 27-29.

5. Bruenjes J.D., Vallabhajosyula S., Vacek C.J., Fixley J.E. Acute pancreatitis-induced takotsubo cardiomyopathy in an african american male. ACG Case Rep. J. 2015; 9: 53-56.

6. Roy R.R., Hakim F.A., Hurst R.T. et al. Two cases of apical ballooning syndrome masking apical hypertrophic cardiomyopathy. Tex. Heart Inst. J. 2014; 41: 179-183.
7. Cheezum M.K., Willis S.L., Duffy S.P. et al. Broken pancreas, broken heart. Am. J. Gastroenterol. 2010; 105: 237-238.

8. Komamura K., Fukui M., Iwasaku T. et al. Takotsubo cardiomyopathy: Pathophysiology, diagnosis and treatment. World J. Cardiol. 2014; 6: 602-609.

9. Scantlebury D.C., Prasad A. Diagnosis of takotsubo cardiomyopathy. Circ. J. 2014; 78: 2129-2139.

10. Van de Walle S.O., Gevaert S.A., Gheeraert P.J. et al. Transient stress-induced cardiomyopathy with an "inverted takotsubo" contractile pattern. Mayo Clin. Proc. 2006; 81: 1499-1502.

11. Sankri-Tarbichi A.G., Mathew P.K., Matos M., Hsi D. Stress-related cardiomyopathy. Heart Lung 2007; 36: 43-46.

12. Ro T.K., Lang R.M., Ward R.P. Acute pancreatitis mimicking myocardial infarction: evaluation with myocardial contrast echocardiography. J. Am. Soc. Echocardiogr. 2004; 17: 387-390. 